\title{
Transition to Federalism in Nepal
}

\author{
Serdar Yilmaz (corresponding author)
}

The World Bank, 1818 H Street NW, DC 20433, USA

Tel: 1-202-473-9350 E-mail: syilmaz@worldbank.org

\begin{abstract}
Syed Khaled Ahsan
The World Bank, Plot E-32, Agargaon, Sher-e-Bangla Nagar, 1207, Dhaka, Bangladesh
\end{abstract}

Tel: 1-202-569-4340_E-mail :sahsan2@worldbank.org

\begin{abstract}
Gabriel Dedu
The World Bank, Yak and Yeti Hotel Complex, Durbar Marg, Kathmandu, Nepal

Tel: 1-202-766-8679 E-mail: gdedu@worldbank.org
\end{abstract}

Saurav Shamsher J.B. Rana

The World Bank, Yak and Yeti Hotel Complex, Durbar Marg, Kathmandu, Nepal

Tel: 1-977-9808905676Ｅ-mail: sauravsjbrana@gmail.com

Received: May 20, 2020 Accepted: June 16, $2020 \quad$ Published: June 19, 2020

doi:10.5296/csbm.v7i1.17066 URL: https://oi.org/10.5296/csbm.v7i1.17066

\begin{abstract}
Nepal embarked on a full-fledged federal system with the adoption of a new Constitution in 2015. Progress has been made in terms of setting up of key institutional structures, and strengthening the regulatory environment for federalism, and to some extent staff deployment. But significant gaps still exist between the needs and existing capacity at all levels of government. A Federalism Capacity Needs Assessment (FCNA) was conducted in 2018-19 for the Government of Nepal (GoN). The FCNA used a broad definition of capacity, including organizational (physical and human) and institutional (laws and regulations) elements. This paper presents progress in the implementation of federalism based on the findings of the FCNA.
\end{abstract}

Keywords: Federalism, Subnational governments, Needs assessment 


\section{Introduction}

Federalism is taking roots in Nepal. Since the adoption of the federal constitution in 2015, Nepal has adopted legislations and put in place institutional structures, intended to roll-out federalism. Within the first two years of their operation, subnational governments (SNGs) have accounted for about $34 \%$ of national budget, significantly boosting their fiscal capacity. However, Nepal faces longer term challenges in managing the transition to federalism. Despite the increased flow of transfers to SNGs, budget execution by SNGs remains low, averaging $61 \%$ in 2018 , with adverse consequences for delivery of public services and quality of spending. In addition, while progress was achieved in terms of the deployment of staff, setting up of key institutional structures, and strengthening of the regulatory environment for federalism, significant gaps still exist between the needs and existing capacity at all levels of government. The legal and regulatory frameworks envisioned in the constitution are yet to be fully implemented. More importantly, like all new federal governments, Nepal is confronted by capacity deficits to manage new functions. There is also lack of clarity in the delegation of functions; more clarity is required on the exact roles of functional assignments devolved to provincial and local levels.

This paper presents progress in the implementation of federalism since the adoption of the 2015 Constitution. The discussions are based on a Federalism Capacity Needs Assessment (FCNA) which was carried out by Georgia State University and Nepal Administrative Staff College for the Government of Nepal (GoN) in 2019. The FCNA has identified the gap between the needs and the capacity of all levels of government to manage their assigned service responsibilities under the new system. It assessed the capacity of the federal government to regulate and manage the way the federalism transition is rolled out, and its capacity to manage the intergovernmental system thereafter.

This paper presents a unique case study of transition to a federal state from a very centralized one in the context of post-conflict recovery. By summarizing the lessons learned from Nepal's transition to a federal system, the paper contributes to multidisciplinary literature on the relationship between conflict and decentralization; capacity and decentralization; sequencing of decentralization reforms and determinants of success in public service reforms. In terms of conflict and decentralization, despite the disagreement in the literature about the sustainability of peace and effectiveness of decentralization as a post-conflict stabilization tool, the consensus seems to be that a lot depends on the country context (Dickovick, 2014; Edwards \& Yilmaz, 2016). This paper employs qualitative methods for better understanding of the country context in the implementation of federalism and asses the durability of new federal institutions to safeguard the peace dividends of the new system. The literature on the relationship between capacity and decentralization is very rich with country case studies (Kim \& Yoon, 2018; Rao Seshadri \& Kothai, 2019; Rocha, Orellano, \& Nishijima, 2016). Our paper contributes to this literature by analyzing the capacity constraints in the implementation of federalism at the federal and sub-national levels. Last but not least, Nepal case study contributes to the literature on the sequencing of decentralization reform (Bahl \& Martinez-Vazquez, 2013) and determinants of successes of large-scale public sector reforms in developing countries (McCourt, 2018). Nepal case study presents familiar themes, such as "political will to reform" "resistance to change" and "ownership of development priorities", 
found in the literature (McCourt, 2018). All in all, this unique case study provides an opportunity to test the validity and robustness of arguments made in the broader literature on decentralization, post-conflict recovery, and large-scale reforms of the public sector.

\section{Federalism Implementation Progress Since 2015}

Nepal is a very diverse country with 101 ethnic groups and 36 castes speaking over 92 languages. It is divided into three regions by topography: the Himalayan (mountains), the hills and the Terai (plain land). The upper caste people from Himalaya and hill regions are better placed in all spheres of the society in Nepal - politics, administration and business.

The failure of the leaders to understand and address peoples' needs, and aspirations resulted in a decade-long insurgency and bloodshed, which led to removal of the constitutional monarchy in May 2008 and eventually the adoption of the 2015 Constitution. Federalism emerged as a consensus formula and solution to a long-standing ethnic and political conflict of the country. It allowed for taking measures towards regional self-governance and empowerment of citizens to enhance civic engagement in a democracy.

The 2015 Constitution has established a federal structure comprising federal, provincial, and local governments. Seven provinces have been established. In March 2017, about 3,920 Village Development Committees and 58 municipalities - spread across 75 districts-were consolidated into 753 local government units. This was followed by the first local level elections in twenty years. In addition to the local elections, the provincial and federal elections were completed by January 2018. The emergence of subnational government units with authority to manage resources carries important implications for service delivery and for fostering a path to transparent and inclusive governance and development, key to addressing root causes of conflict and fragility.

\section{a. Devolution of Functions}

The Constitution of Nepal specifies a new and more decentralized assignment of expenditure responsibilities to each sphere of government, which in turn requires a significant redistribution of government employment from the federal to the provincial and local government levels. In terms of functions, decision-making authority for certain functions have been devolved to provincial and local governments (see 


\section{Macrothink}

Table 1). However, the Constitution delegates residual powers to the federal government which has implications for the devolution of powers to provincial and local governments. In terms of funds, the Constitution divides powers relating to tax and non-tax sources of revenue amongst federal, provincial and local governments. There are no new taxes in the three Schedules of the Constitution as compared to the pre-2015 period. However, there is a reassignment of existing taxes that were being levied by the central government in the past. In addition, Schedules 7 and 9 of the Constitution provide the concurrent list of revenues to be shared between the different tiers of the government. 
Table 1. Basis of allocation of functions between three tiers of government

\begin{tabular}{lll}
\hline Federal & Sector Policymaking; National Regulations and Standards; Specialized Services; \\
& Research and Development; Inter-provincial Coordination; Foreign policy; Projects and \\
& programs considered of national importance
\end{tabular}

Source: FCNA report.

\section{b. Devolution of Funds}

The Intergovernmental Fiscal Arrangement Act in Nepal provides for 30 percent of the federal government tax collection from excise tax and Value Added Tax (VAT) on domestic goods is to be shared 50:50 with the relevant SNG. In addition, the federal government allocates additional funds for financing the intergovernmental grants; namely, equalization grant, conditional grant, special grant and complementary grant. In FY2019, the federal government budgeted for an amount equivalent to 53 percent of all national tax collections to SNGs as transfers through the grant system and tax sharing. By international standards, this is a large share.

Table 2 provides the total amount of grant resources - vertical shares - going to subnational governments for FY2018 and FY2019.

Table 2. Intergovernmental Transfers: Vertical Shares

\begin{tabular}{|l|l|l|l|l|}
\hline \multicolumn{2}{|l|}{} & Amount (NPR millions) & Percentage & Percent of \\
Distribution & GDP \\
\hline \multirow{2}{*}{$\begin{array}{l}\text { FY2018 } \\
\text { (actual) }\end{array}$} & Equalization grants & 155,898 & 64.6 & 5.1 \\
\cline { 2 - 5 } & Conditional grants & 85,273 & 35.4 & 2.8 \\
\hline
\end{tabular}




\begin{tabular}{|c|c|c|c|c|}
\hline & Complimentary grants & - & 0 & 0 \\
\hline & Special grants & - & 0 & 0 \\
\hline & Tax sharing grants & - & 0 & 0 \\
\hline & Total & 241,171 & 100 & 7.9 \\
\hline \multirow{6}{*}{$\begin{array}{l}\text { FY2019 } \\
\text { (estimate) }\end{array}$} & Equalization grants & 135,506 & 36.4 & 3.9 \\
\hline & Conditional grants & 117,640 & 31.6 & 3.4 \\
\hline & Complimentary grants & 10,000 & 2.7 & 0.3 \\
\hline & Special grants & 6,800 & 1.8 & 0.2 \\
\hline & Tax sharing grants & 102,453 & 27.5 & 3 \\
\hline & Total & 372,399 & 100 & 10.8 \\
\hline \multirow{6}{*}{$\begin{array}{l}\text { FY2020 } \\
\text { (budget) }\end{array}$} & Equalization grants & 145,246 & 31.3 & 3.9 \\
\hline & Conditional grants & 168,420 & 36.3 & 4.5 \\
\hline & Complimentary grants & 10,000 & 2.2 & 0.3 \\
\hline & Special grants & 10,000 & 2.2 & 0.3 \\
\hline & Tax sharing grants & 130,895 & 28.2 & 3.5 \\
\hline & Total & 464,561 & 100 & 12.3 \\
\hline
\end{tabular}

Source: Government of Nepal, Budget FY 2018/2019 and 2019/2020

Conditional grants are the most important source of revenue for both provincial and local governments (see Table 3). They are used mostly to guarantee the cost of salaries of transferred central government employees (mostly in the education and health sectors) and to cover the costs of legacy projects from the pre-2015 period. Less important in the present system are special and complimentary grants that are distributed to defray part of the cost of local implementation of special projects of the federal government. Tax sharing and equalization grants are distributed by two different formulae, but both are based on indicators of expenditure needs and are unconditional transfers. The formulae were developed by the NNRFC. 
Table 3. Intergovernmental Transfers, 2018 and 2019, by Percent Distribution

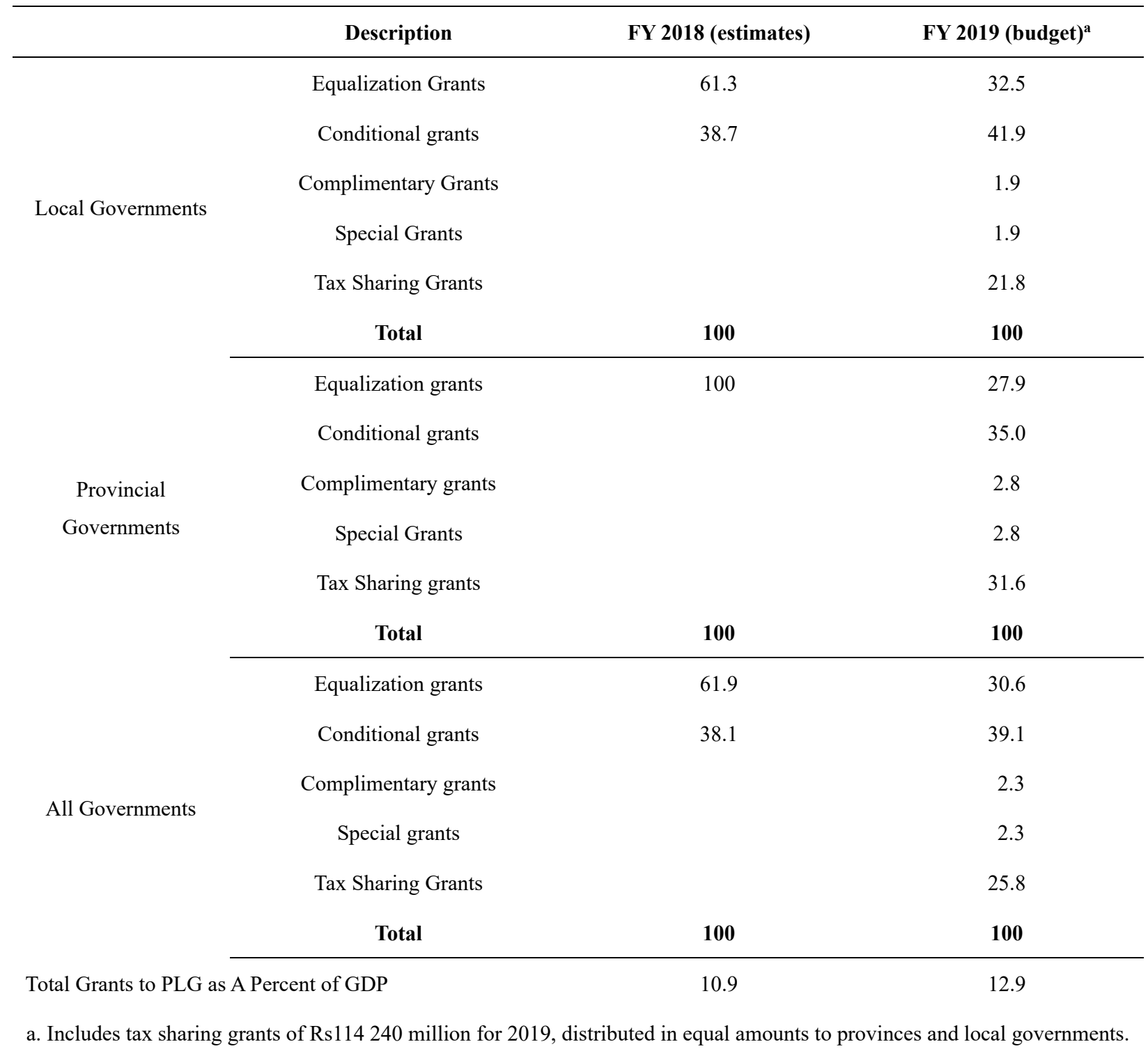

Source: Government of Nepal, Budget Speech FY 2018/2019.

The present intergovernmental fiscal system presents no significant incentives to provincial or local governments for revenue collection. In fact, elected local officials hesitate to impose taxes on their constituents although the Constitution affords them. The Constitution and the Intergovernmental Fiscal Arrangement Act provide the legal basis and define the exclusive and concurrent lists of revenue instruments available to provincial and local governments. SNGs have some powers to pass their own tax laws and have some rate-setting discretion. Further, some of the local tax sources that have been assigned to SNGs have good revenue potential. These include taxes on real property and real property transfers, taxes on motor vehicles, and certain user charges. Therefore, to maintain or expand the fiscal space, there is a place for local government taxation in Nepal, particularly for urban local governments as well 
as the provincial governments. It might be a good idea to introduce incentives for increased use of local taxing and user charge powers. The intergovernmental transfers formula could include allocation of certain types of grants based on the fiscal efforts of SNGs.

\section{c. Devolution of Functionaries}

In terms of functionaries, the Constitution envisions the establishment of civil service and public service commissions at the federal and provincial levels. At the federal level, the 2017 Civil Service Act (CSA) harmonized rules and regulations governing the civil service. The Civil Servant Adjustment Act of 2019 and the Act determining the bases and criteria on roles and responsibilities of the provincial public service commission (PPSC) paved the way for the provincial governments to prepare their legislations to establish PPSCs within the framework given by the federal law. Currently, the Government of Nepal's civil service employs 89,825 individuals, 25 percent of whom are female. However, total government employment is much broader, including for example, teachers, police, and permanent employees of local governments; but they are not classified as civil service employees. So, when all employees (excluding teachers) are considered, it is estimated that total government employment is 126,852 (about one government worker for every 230 population in Nepal).

The transition to the new federal system requires the "adjustment" of these 89,825 civil service employees. Some of these employees have been physically relocated to become employees of either provincial governments or local governments while some will remain with the federal government. The wages and salaries of those assigned to the subnational level will be paid by their respective SNGs, but their benefits will continue to be paid by the federal government.

The number of employees to be devolved from the federal level has been determined in two steps. The first, which follows the new assignments of expenditure responsibility, was for the federal government to wind up certain offices and transfer all employees in those departments to the provincial and local governments. Most of these are service delivery workers, many of whom are already working at the provincial and local government level on a secondment basis. This is the largest component of "adjusted" employees. The second step was to reduce the number of the remaining federal civil service employees to address weaknesses in the management structures of provincial and local governments. To do this, the Ministry of Federal Affairs and General Administration (MOFAGA) conducted an organization and management (O\&M) survey of each federal government ministry to establish federal employment needs. The difference between the number "needed" by the federal ministry and the number of present employees is the redundant employees who needed to be "adjusted" to the provincial and local government levels.

These two approaches to employment devolution have led to a proposed reduction in civil servant employment of the federal government by 41,335 or about 46 percent of total civil service employment. For those departments to be retained by the federal government, the O\&M survey for civil servants led to a proposal for the retention of 48,490 civil service positions. As compared to the 51,420 existing positions in the departments to be retained by the federal government, this was a decrease of 2,930 positions. In other words, 2,930 public administration/public management employees could be potentially reallocated to provincial and local government posts in addition to those that were already serving in a seconded 
capacity at various subnational government offices and service centers.

Interim O\&M surveys were conducted by the federal government for the provincial and local governments. The proposal based on these surveys is for 21,399 employees across the seven provincial governments. For rural local governments, O\&M surveys were carried out on the basis of local government size classifications (rural, municipality, metropolitan, etc.) rather than individual O\&Ms, as were carried out for each provincial government. The total employment needs of all local governments were calculated by multiplying the needs for each local government category by the number of local governments in that category. Across the 753 local (municipal and rural) governments, 33,262 civil servants are proposed, based on these interim O\&M analyses. This number includes positions at the municipal offices (local government headquarters) and all associated ward offices. However, it does not include sectoral delivery units in agriculture, livestock and health positions etc. With these, the total proposed positions for local governments (including for sectoral service delivery) are 66,750.

To fill these positions and assist with the adjustment of civil service across the three levels of government, the GoN fielded a questionnaire asking civil servants to identify and rank their preferred level of service. Based on the response to this questionnaire, staff were assigned to either the federal, province or local government, considering the individual's experiences, skills and the needs at vacant positions. One level of adjustment exercise across the three levels of government was completed on March 28, 2019.

Individual employees have been assigned to their new posts, and their physical relocation is now underway. Based on the survey, a total of 39,960 individuals have been assigned to the federal government, 13,821 have been assigned to provincial governments, and 31,710 to the local governments. In the case of local governments, 12,097 legacy staff have also been assigned to new positions. Thus, the total adjusted staff at the local government level is 43,807. An additional 2,443 civil service employees have been in a reserve pool and have not yet been assigned positions. Thus, the unfilled employment gap as of March 2019 is 39,051 (

Table 4). If the reserve pool is assigned to provincial and local governments, the net employment deficit across the three levels of government would be 36,608, and it is largest at the provincial level when measured relative to the total number of proposed positions. This gap includes both service delivery personnel and public administration/public management personnel.

Table 4. Interim Post Adjustment Human Resource Gap at Three Levels of Government

\begin{tabular}{llllll}
\hline & Proposed & Adjustment & Post-Adjustment Gap & Reserve Pool & Final Gap \\
\hline Local & 66,750 & 43,807 & $-22,943$ & \\
Province & 21,399 & 13,821 & $-7,578$ & \\
Federal & 48,490 & 39,960 & $-8,530$ & & $\mathbf{2 , 4 4 3}$ \\
Total & $\mathbf{1 3 6 , 6 3 9}$ & $\mathbf{9 7 , 5 8 8}$ & $\mathbf{- 3 9 , 0 5 1}$ & $\mathbf{- 3 6 , 6 0 8}$ \\
\hline
\end{tabular}

Source: Compiled from the data provided by MOFAGA, Government of Nepal, and team calculations. 
Even with the employee adjustment underway, there are issues that still need to be resolved. Firstly, how will the subnational governments fill the estimated gap of 36,000 in public administration/public management positions and service delivery position? Although provincial and local governments can carry out their own O\&M surveys and recruit additional employees through the provincial public service commissions, these commissions have not been established yet. The provincial and local governments are waiting for the federal government to enact a framework legislation for the establishment of provincial public service commission. Therefore, it is urgent for the framework legislation to be enacted and province civil service/local service legislations to be passed to enable the provincial and local governments to hire new employees.

Secondly, will the skills of the relocated federal bureaucrats and the legacy employees of the local governments fit the needs of the subnational governments? It is not clear what recourse the provincial and local governments have to address skill mismatches. According to federal government officials, the expectation is that local governments will do their own O\&M survey after the initial round of relocations are in place. But it is not clear whether SNGs will have funds and proper institutional set up to attract new employees with the right skill sets.

Thirdly, it is not clear whether there is a financing plan in place to ensure that the budget supports these employment increases. Funding for the adjusted federal bureaucrats and any new hires will primarily come from federal grants, with vertical shares that are mostly decided as part of the annual budget process. A financing plan would require analysis of the match between revenues from the present formula-based conditional and unconditional grant allocations (and locally raised revenues) and the cost requirements for all new employees.

Finally, since the new civil service legislations at all levels are not in place, it is not yet clear how gender balance and representation of disadvantaged groups will be addressed in the new employment structure at the subnational government level. To the extent that women and minorities will be given special consideration, this will likely come from the hiring rules that accompany the new Federal Civil Service Act, and from the Provincial Civil Service Commission hiring rules.

\section{Subnational Capacity Constraints}

\section{a. Provincial Governments Capacity Needs Assessment}

\section{Physical Infrastructure}

Most provincial governments are in the process of selecting the location of their capitals. As such, the FCNA assessed the adequacy of existing infrastructure in terms of the provincial governments' ability to discharge their functions from their temporary offices.

With a few exceptions, most provincial governments do not own their office space. In most cases, they can use existing federal (or in some cases municipal) buildings without having to pay rent. Given the current vacancy levels (which range between one quarter and one half of approved positions), the existing office space is generally adequate for the existing staff. On average, there are less than two employees per room. However, in Provinces 5 and 6, half of the ministries have office space below the required size or quality. The availability or size of meeting rooms is an issue in some ministries in Provinces 2, 3 and 5. More importantly, more 
than half of the provinces do not have adequate space to accommodate meetings of provincial assemblies or cabinets.

Each province has between 30-50 four-wheel vehicles (sedans, vans, jeeps) and 50-90 two-wheel vehicles (motorcycles and scooters), with Province 6 (Karnali) having the least and Province 5 having the most. This translates into roughly one car and two motorcycles/scooters per seven existing employees. Generally, ministerial offices in all provinces have access to electricity, telephone and internet. Gandaki (Province 4) experiences frequent blackouts though. The provincial governments have supply of computers for their essential staff, while they are not connected through a network that would allow staff to access and manage integrated data systems.

At present, provincial governments do not practice a long-term (lifecycle) approach on management, maintenance, renewal, and development of assets. They do not have ownership titles for the buildings that they are currently occupying. They have only a paper-based asset inventory system. There are no procedures in place to collect data on operating and maintenance costs for major asset items. There is no system in place for monitoring and recording maintenance work performed and needed.

\section{Human Resource Management}

Provincial administrations were introduced in 2017, and they have been following a uniform interim organizational structure developed by the federal administration. No province has yet conducted its own Organization and Management (O\&M) survey to develop its organizational structure. Even with a uniform interim organization structure in the provinces, there are differences in vacancy rates, ranging from a quarter of approved positions in Gandaki (Province 4) to half in Sudur-Pashchim (Province 7). For all provinces, this adds up to about 1,000 vacant positions in public administration (that is, excluding service centers, such as veterinary clinics). On average, 15 percent of existing staff are contract employees, primarily for support functions, such as office assistants and drivers. But a few are more skilled employees, such as computer operators.

The HR policies and guidelines have not been developed for managing approval of leave, performance appraisal etc. in the provincial administrations. All provincial administrations are now staffed with civil servants seconded from the federal government, and the federal policies are being followed in managing them. Some provinces have developed their own policies for managing contractual staff (e.g., Province 5). Only Province 1 has developed job descriptions for all positions in all provincial ministries. Most provinces have descriptions of roles and responsibilities for various sections within provincial ministries but not by positions. However, many provinces are planning or are in the process of developing job descriptions for individual positions and already have it done for at least one ministry in each province, except Gandaki (Province 4).

\section{Public Financial Management}

No province had a multi-year development plan at the time of the FCNA survey. However, most provinces had begun the process to develop one by forming a dedicated commission. In all cases, the planning horizon is for five years. Except for Province 3, provinces do not have any sector-specific plans either. All provinces have annual investment plans, which are 
broken down by ministry. In terms of budget preparation, SNGs use different systems. While Sub-National Treasury Regulatory Application (SUTRA) was used by most local governments to prepare the 2018/19 budget, at the time of the interviews, provinces were uncertain as to which software and budget format to use for FY 2019/20. Province 1 was transitioning to the Nepal Public Sector Accounting Standards (NPSAS) software. Province 3 was planning to use Line Ministry Budget Information System (LMBIS). Provinces 5 and 6 were waiting for guidelines from the federal government.

While most provinces have a section dedicated to revenue collection, it is often understaffed and busy dealing with other tasks. There appears to be dual subordination of some offices to both federal and provincial authorities. District land revenue offices, for example, which collect the land transfer fee, report to both. In terms of auditing, most provinces do not have their own arrangements (regulations, manuals, guidelines) in place for internal audits, and they rely on federal legislation and guidelines. All provinces adopted their own procurement guidelines and standards. However, half of the provinces acknowledge having limited capacity for procurement. Most provinces lack mechanisms to assess suppliers and their performance. There are no mechanisms for appeals against decisions made in relation to procurement transactions other than the general grievance redress systems.

\section{Gender Equality and Social Inclusion}

No province has a comprehensive Gender Equality and Social Inclusion (GESI) policy. No province has a GESI strategy either. They don't have a framework for promoting women's leadership in provincial governments. No GESI audit has been conducted yet by any provincial government.

\section{Accountability and Transparency}

To share the decisions of provincial assemblies with the citizens, provinces use a variety of methods. Websites and press releases are the most commonly used methods. There are also designated information officers in each of the ministries. No province has prepared a Citizens' Charter to inform citizens on how to access provincial services. While expenditure statements are published on the provincial government websites at least quarterly, not all provinces report revenues. No province publicizes its budget in a simple format (i.e., provincial government citizens' budget). The officials who were interviewed do not appear to be familiar with this concept. Most provinces have some mechanism for responding to citizen grievances, while its utilization and response rates vary.

\section{b. Local Governments Capacity Needs Assessment}

\section{Physical Infrastructure and Connectivity}

More than half (54 percent) of the local governments own at least some of their buildings. Among those local governments that own their own buildings, 17 percent also rent additional space and 4 percent are also temporarily using other public buildings. Out of the 46 percent who did not own any buildings, over 80 percent had to rent at least some of the office space and the remaining local governments temporarily using other public buildings only. Differences in ownership are most evident by type of municipality, with all cities owning buildings, while only 38 percent of rural municipalities owned buildings (

Table 5). 
Construction of office building is underway for almost half; that is, 47 percent of the local governments. This is a proportion that is approximated across most comparisons, except in the Himalayan ecological zone (HEZ) where only 24 percent of local governments had construction projects and Province 6, which has only 10 percent of local governments reporting construction. Surprisingly, construction takes place in less than one half of the local governments without any building but in more than half of those that already own some building(s).

Table 5. Owned vs Rented Local Government Buildings \& Average Rooms

\begin{tabular}{|l|l|l|l|}
\hline & Buildings Owned & Buildings Rented & Average Number of Rooms \\
\hline Metro & $100 \%$ & $18 \%$ & 63 \\
\hline Urban & $61 \%$ & $56 \%$ & 17 \\
\hline Rural & $38 \%$ & $64 \%$ & 14 \\
\hline All & $\mathbf{5 4 \%}$ & $\mathbf{5 4 \%}$ & $\mathbf{2 2}$ \\
\hline
\end{tabular}

Source: Estimated by the study team based on a representative survey of local governments.

Some 82 percent of local governments are connected to the national grid, but in Province 6 this figure is only 20 percent. In the HEZ, there is a greater reliance on solar power, with 82 percent of HEZ local governments utilizing it, and a lower national grid connectivity, with only 35 percent connected to the national grid. Nationally, 89 percent of all local governments have a back-up electrical system.

Local governments averaged 44 desktop computers and 17 laptops, with metropolitan municipalities, Terai Ecological Zones (TEZ) and Province 2 having more than their counterparts. Metro municipalities averaged 47 laptops and 199 desktops, compared to 14 and 24 respectively in urban local governments, as well as 11 and 12 respectively in rural local governments. Substantial differences were noted by ecological zone as well: TEZ local governments averaged 16 laptops and 68 desktops, compared to 14 and 13 for HEZ, and 20 and 31 for the Hilly zone. Thus, unlike office space, the number of computers seems to be more aligned with the staff count, at least when compared across different types of municipalities in terms of urbanization. Province 2 local governments averaged 103 desktops, about twice the next highest province's number.

Internet connectivity was high across Provinces 1 through 5, with at least 75 percent of local governments reporting a "functioning internet connection" (

Table 6 ). However, only half of the local governments in Provinces 6 and 7 were connected to internet, and only 41 percent of HEZ local governments, compared to 80 percent for Hilly and 90 percent for Terai regions. Nearly all (98 percent) local governments have access to cellular telephone networks, with 68 percent calling it reliable and another 25 percent calling it "somewhat reliable." Only 10 percent of Province 6 local governments called their cellular connection reliable, while HEZ had 24 percent with reliable cellular connections and 51 percent of rural local governments. Most local governments (60 percent) reported that their 


\section{Macrothink}

ward offices do not have landlines and 10 percent reported wards not having access to a mobile network. Metropolitan local governments were most likely to have one or the other for their wards and rural local governments were the least likely.

Table 6. Portion of Local Governments with Internet Connections and Reliable Cellular Connections, by Province

\begin{tabular}{|l|l|l|}
\hline Province & Able to Connect to Internet & Reliable Cellular Access \\
\hline Province 1 & $86 \%$ & $71 \%$ \\
\hline Province 2 & $90 \%$ & $81 \%$ \\
\hline Province 3 & $80 \%$ & $75 \%$ \\
\hline Province 4 & $75 \%$ & $83 \%$ \\
\hline Province 5 & $89 \%$ & $78 \%$ \\
\hline Province 6 & $50 \%$ & $10 \%$ \\
\hline Province 7 & $50 \%$ & $50 \%$ \\
\hline
\end{tabular}

Source: Estimated by the study team based on a representative survey of local governments.

Nearly all local government centers were accessible by road. Only in provinces 6 and 7, 10 percent or fewer local governments reported that they were not connected by road. Overall, half of local governments have blacktopped roads to their centers, but only about a quarter of local governments in HEZ region have blacktopped roads. Provinces 2 and 6 have the lowest portion of local governments with blacktopped roads: 26 percent and 20 percent, respectively.

\section{Human Resource Management}

Local governments across the country have a shortage of human resources as illustrated in 
Table 7. Overall, there is a shortage of 5500 individuals compared to the number of positions envisioned in local government structures (approved positions). However, the magnitude of the shortage is somewhat masked by the surplus of 3,300 positions in the "miscellaneous" category, which mostly consists unskilled workers like cleaners, office assistants, and drivers. Two thirds of them are contract staff rather than permanent employees.

The shortage of high-skill staff is even more striking as shown in

Table 8 , which indicates the percentage of vacancies by service group and type of municipality. One can see a particularly high vacancy rate for engineers: almost one half nationwide and over two thirds in sub-metropolitan municipalities. Surprisingly, vacancy rates increase with the level of urbanization. While small in absolute numbers, there is a surplus of health and livestock professionals, especially in metropolitan municipalities. 
Table 7. Approved and Filled Positions Across 753 Local Governments

\begin{tabular}{|l|l|l|l|l|l|l|l|l|l|l|l|}
\hline & $\begin{array}{l}\text { General } \\
\text { Admin. }\end{array}$ & $\begin{array}{l}\text { Revenue/ } \\
\text { Account }\end{array}$ & Engin & Agric & Educ & Law & Health & Livestk & Misc. & Total & Misc. \\
\hline $\begin{array}{l}\text { Approved } \\
\text { positions }\end{array}$ & 20,043 & 2,714 & 8,338 & 1,890 & 1,777 & 307 & 4,680 & 2,021 & 9,004 & 50,774 & 41,770 \\
\hline Filled positions & 16,232 & 1,880 & 4,650 & 1,750 & 1,263 & 190 & 5,038 & 1,967 & 12,268 & 45,237 & 32,970 \\
\hline Out of which & & & & & & & & & & & \\
wdjusted & 145 & 5 & 16 & 3 & 6 & 0 & 5 & 7 & 21 & 208 & 187 \\
\hline Deputed & 7,746 & 1,443 & 1,062 & 796 & 964 & 29 & 3,448 & 953 & 1,777 & 18,217 & 16,441 \\
\hline Contract & 4,825 & 139 & 2,653 & 839 & 248 & 112 & 1,400 & 855 & 7,980 & 19,052 & 11,072 \\
\hline LB Staff & 3,517 & 293 & 919 & 111 & 45 & 49 & 185 & 151 & 2,490 & 7,760 & 5,270 \\
\hline Gap & $\mathbf{3 , 8 1 1}$ & $\mathbf{8 3 4}$ & $\mathbf{3 , 6 8 8}$ & $\mathbf{1 4 0}$ & $\mathbf{5 1 4}$ & $\mathbf{1 1 7}$ & $\mathbf{- 3 5 8}$ & $\mathbf{5 5}$ & $\mathbf{- 3 , 2 6 3}$ & $\mathbf{5 , 5 3 7}$ & $\mathbf{8 , 8 0 0}$ \\
\hline
\end{tabular}

Source: Estimated by the study team based on a representative survey of local governments.

Engin $=$ Engineering, Agric $=$ Agriculture, Educ $=$ Education, Livestk $=$ Livestock and Misc .

$=$ Miscellaneous

Table 8. Vacancy (+) or Redundancy (-) Rate for Approved Positions, by Local Government Type

\begin{tabular}{|l|l|l|l|l|l|l|l|l|l|l|l|}
\hline & $\begin{array}{l}\text { General } \\
\text { Admin. }\end{array}$ & $\begin{array}{l}\text { Revenue/ } \\
\text { Account }\end{array}$ & Engin & Agric & Educ & Law & Health & Livestk & Misc. & Total & $\begin{array}{l}\text { Misc. } \\
\text { Wotal }\end{array}$ \\
\hline $\begin{array}{l}\text { Metro-politan } \\
21 \%\end{array}$ & $57 \%$ & $64 \%$ & $20 \%$ & $59 \%$ & $30 \%$ & $-24 \%$ & $-43 \%$ & $-27 \%$ & $14 \%$ & $55 \%$ & \\
\hline $\begin{array}{l}\text { Sub- } \\
\text { Metro-politan }\end{array}$ & $42 \%$ & $50 \%$ & $74 \%$ & $39 \%$ & $40 \%$ & $45 \%$ & $-81 \%$ & $7 \%$ & $-101 \%$ & $34 \%$ & $92 \%$ \\
\hline $\begin{array}{l}\text { Urban } \\
\text { Muni-cipality }\end{array}$ & $21 \%$ & $18 \%$ & $40 \%$ & $11 \%$ & $30 \%$ & $58 \%$ & $4 \%$ & $-2 \%$ & $-24 \%$ & $14 \%$ & $29 \%$ \\
\hline $\begin{array}{l}\text { Rural } \\
\text { Muni-cipality }\end{array}$ & $12 \%$ & $34 \%$ & $35 \%$ & $5 \%$ & $26 \%$ & $13 \%$ & $-12 \%$ & $5 \%$ & $-53 \%$ & $4 \%$ & $16 \%$ \\
\hline Total & $\mathbf{1 9 \%}$ & $\mathbf{3 1} \%$ & $\mathbf{4 4 \%}$ & $\mathbf{7 \%}$ & $\mathbf{2 9 \%}$ & $\mathbf{3 8 \%}$ & $\mathbf{- 8 \%}$ & $\mathbf{3 \%}$ & $\mathbf{- 3 6 \%}$ & $\mathbf{1 1 \%}$ & $\mathbf{2 7 \%}$ \\
\hline
\end{tabular}

Source: Estimated by the study team based on a representative survey of local governments.

One should note that these numbers capture present staff, whether inherited from the previous local bodies, seconded from the national civil service or adjusted from the federal into subnational civil service (very rare at the time of the survey). The shortage of technically skilled human resources will impact specific sectors. As illustrated in 
Table 9 , forestry and law are the two sectors that suffer the most from the lack of technically skilled staff. In addition, there are shortages of technical expertise specific to different types of municipalities. Rural municipalities have more acute challenges in the education and infrastructure sectors. By contrast, for metropolitan municipalities, more pressing needs are in information technology (IT), land/building, planning, and waste management.

Table 9. Proportion of Local Governments that See Services Disrupted/Lacking Due to Insufficient Staff, by Function

\begin{tabular}{|c|c|c|c|c|c|}
\hline & Metro-politan & Sub-Metro-politan & Urban Muni-cipality & Rural Muni-cipality & All Local Governments \\
\hline Administration & $33 \%$ & $91 \%$ & $81 \%$ & $71 \%$ & $74 \%$ \\
\hline Plan & $67 \%$ & $91 \%$ & $72 \%$ & $76 \%$ & $76 \%$ \\
\hline Information \& technology & $67 \%$ & $73 \%$ & $44 \%$ & $53 \%$ & $53 \%$ \\
\hline Account & $33 \%$ & $64 \%$ & $61 \%$ & $61 \%$ & $60 \%$ \\
\hline Land/Building & $67 \%$ & $64 \%$ & $61 \%$ & $66 \%$ & $64 \%$ \\
\hline Forest & $50 \%$ & $100 \%$ & $100 \%$ & $93 \%$ & $93 \%$ \\
\hline Education & $33 \%$ & $73 \%$ & $58 \%$ & $81 \%$ & $70 \%$ \\
\hline Health & $33 \%$ & $73 \%$ & $47 \%$ & $45 \%$ & $48 \%$ \\
\hline Agriculture & $17 \%$ & $73 \%$ & $61 \%$ & $65 \%$ & $62 \%$ \\
\hline Infrastructure Development & $50 \%$ & $73 \%$ & $58 \%$ & $77 \%$ & $70 \%$ \\
\hline Law & $67 \%$ & $82 \%$ & $83 \%$ & $89 \%$ & $85 \%$ \\
\hline Environment & $50 \%$ & $73 \%$ & $72 \%$ & $66 \%$ & $68 \%$ \\
\hline Waste Management & $67 \%$ & $64 \%$ & $61 \%$ & $61 \%$ & $62 \%$ \\
\hline Other & $0 \%$ & $9 \%$ & $17 \%$ & $11 \%$ & $12 \%$ \\
\hline
\end{tabular}

Source: Estimated by the study team based on a representative survey of local governments.

Less than a third of the local governments, mainly metropolitan municipalities and some urban municipalities, report having their own laws/policies for managing their staff, in terms of leave approval, performance appraisal reporting relations etc.

Over 8,000 local staff have not attended any training since the local elections in 2017. This represents almost one fifth of all staff present in local governments, but for sub-metropolitan municipalities, this represents over one third of their existing staff ( 
Table 10). However, only half of the local governments have prepared capacity building plans for either employees or elected officials. 
Table 10. Estimated Number of Staff Not Participated in Any Training on a Relevant Subject After Formation of Local Government

\begin{tabular}{|l|l|l|l|l|l|}
\hline & Metropolitan & Sub-metropolitan & Urban Municipality & Rural Municipality & Grand Total \\
\hline Province 1 & 0 & 0 & 981 & 499 & 1,480 \\
\hline Province 2 & 12 & 36 & 562 & 229 & 839 \\
\hline Province 3 & 320 & 140 & 649 & 1,021 & 2,130 \\
\hline Province 4 & 40 & 0 & 321 & 210 & 571 \\
\hline Province 5 & 0 & 309 & 328 & 394 & 1,031 \\
\hline Province 6 & 0 & 0 & 342 & 964 & 1,306 \\
\hline Province 7 & 0 & 170 & 520 & 332 & 1,021 \\
\hline Total & $\mathbf{3 7 2}$ & $\mathbf{6 5 5}$ & $\mathbf{3 , 6 9 5}$ & $\mathbf{3 , 6 2 1}$ & $\mathbf{8 , 3 4 3}$ \\
\hline Percent of present staff & $8.37 \%$ & $35.85 \%$ & $19.63 \%$ & $17.97 \%$ & $18.44 \%$ \\
\hline
\end{tabular}

Source: Estimated by the study team based on a representative survey of local governments.

\section{Planning and Public Financial Management (PFM)}

The survey results show vast differences between local governments and provinces in the area of planning and PFM. Only a quarter of Nepali local governments have multi-year development plans and this proportion ranges from 10 percent in Provinces 4 and 6 to 50 percent in Province 7. Where such a plan exists, planning almost always involved public consultations. Local governments receiving training on Medium Term Expenditure Framework (MTEF) greatly differ among provinces. Overall, less than a fifth of the local governments have received any training on MTEF, with the proportion ranging from zero in Provinces 4 and 6 to a quarter in Provinces 2 and 7. In terms of municipality type, a higher proportion of metropolitan municipalities received some MTEF training than others.

At the ward level, 58 percent of local governments reported that wards were able to do ward-level planning and the same proportion were able to do monitoring work. Only 38 percent of local governments reported that their wards could do ward-level data management. However, 93 percent of local governments reported that wards are involved in monitoring local government services.

The local governments are developing their PFM capacities. Different software packages are being used by the local governments to prepare budget estimates. Less than 44 percent of local governments use the SUTRA to prepare budget estimate, while 68 percent use Excel. Only 6 percent of HEZ local governments use SUTRA while the rest rely on Excel. Of those that did not use SUTRA, the most commonly cited reason (42 percent) was the lack of trained staff. Out of those who did not use SUTRA last year, 60 percent are ready to use SUTRA for next budget estimates. In just under half of local governments (49 percent), budget estimates followed the SUTRA format, while 30 percent followed the federal format and 5 percent followed FMIS.

In terms of budget execution, two thirds of local governments reported using Microsoft Excel 
while only fifty percent used SUTRA. Nearly all local governments reconciled their accounts periodically since only three local governments never did it. 58 percent of local governments reconciled their accounts monthly, while 21 percent did it quarterly, 10 percent semi-annually, and 9 percent annually. Seventy-nine percent of local governments have studied local revenue sources, with the proportion being lower for rural (less than 75 percent) and higher for urban municipalities (more than 85 percent). Revenue improvement action plans existed in only 25 percent of local governments, but for metropolitan municipalities this proportion was 50 percent. On average, local governments collected 72 percent of estimated revenue. However, between provinces, this ranged from 40 percent in Province 2 to 95 percent in Province 4. In 57 percent of local governments, actual revenue collection was off by more than 25 percent. In these cases, the most common reasons cited were unrealistic estimations (62 percent of cases) and limited personnel (51 percent of cases). Excel was the most common revenue management system utilized, with 37 percent of local governments using it, followed by government developed software (23 percent) and the rest using development partners' or their own software.

Revenue collection was in cash in 66 percent of local governments. Although 93 percent of local governments reported having a branch of commercial bank there. In addition, only about half of the local government that collect revenue in cash deposit the funds daily into bank accounts. On the expenditure side, the average burn-rate of local governments' recurrent budgets was 80 percent and 75 percent for capital budgets. Surprisingly, the burn-rate was lower than the average in metropolitan municipalities with burn rates of 76 percent and 61 percent for recurrent and capital respectively. Those local governments with less than 60 percent capital budget burn-rates identified absence of technical staff ( 29 percent), default by contractor ( 29 percent) and low procurement capacity ( 24 percent) as the main reason for low capital budget execution.

Less than one half of local governments (46 percent) have prepared procurement regulations, though most (83 percent) have a unit in their organizational structure designated to handle procurement. The highest proportion of local governments with procurement regulations at 82 percent is among metropolitan and sub-metropolitan cities, but only 42 percent of urban municipalities and 38 percent of rural municipalities have them. Province 4 has the smallest portion of local governments with procurement regulations, at 17 percent, while Provinces 1 and 2 have the lowest portion of their local governments with a designated unit, at 67 percent and 68 percent respectively (

Table 11).

Table 11. Portion of Local Governments with Procurement Regulations and Functional Procurement Unit in Place, by Province

\begin{tabular}{|c|c|c|}
\hline & Regulations & Functional Units \\
\hline Province 1 & $33 \%$ & $67 \%$ \\
\hline Province 2 & $73 \%$ & $68 \%$ \\
\hline Province 3 & $55 \%$ & $95 \%$ \\
\hline
\end{tabular}




\begin{tabular}{|c|c|c|}
\hline Province 4 & $17 \%$ & $83 \%$ \\
\hline Province 5 & $39 \%$ & $94 \%$ \\
\hline Province 6 & $60 \%$ & $90 \%$ \\
\hline Province 7 & $33 \%$ & $92 \%$ \\
\hline All Provinces & $\mathbf{4 6 \%}$ & $\mathbf{8 3} \%$ \\
\hline
\end{tabular}

Source: Estimated by the study team based on a representative survey of local governments.

The capacity to conduct international bidding is very low amongst local governments, with only 14 percent stating that they have such capacity. On the other hand, at least 94 percent have capacity for national bidding, sealed quotations, direct procurement and through a user's committee. By far, the most commonly used procurement type is the users' committee. However, only 30 percent of local governments have a mechanism to avoid conflict of interest in forming their user committees. In Province 7, no local governments have such a mechanism.

\section{Political Governance and Administration}

Mayors/Chairs are male in 97 percent of local governments and deputy mayors/vice chairs are female in 92 percent of local governments. Over one third, 41 percent of assembly members are female while 21 percent are Dalits. There is little variation in these proportions across provinces, ecological zones and municipality type. More than 80 percent of local assemblies have judicial, legislation, resource projection, revenue and budget committees. Local governments in Province 5 have created the fewest committees, 50 percent have created account and revenue committees and 61 percent have created legislation, social affairs, administration, resource projection, and budget committees.

Almost half, 48 percent of assembly committees have never received status reports from their respective thematic local government sections. Some 27 percent have received them only "sometimes" at an irregular basis.

Table 12 provides the proportion of local governments never receiving thematic section status reports by municipality type and ecological zone.

Table 12. Portion of Local Governments "Never" Receiving Thematic Section Status Reports

\begin{tabular}{|c|c|c|c|}
\hline Metro & $12 \%$ & HEZ & $76 \%$ \\
\hline Urban & $53 \%$ & Hilly Zone & $47 \%$ \\
\hline Rural & $56 \%$ & TEZ & $40 \%$ \\
\hline
\end{tabular}

Source: Estimated by the study team based on a representative survey of local governments.

At least 88 percent of local governments have created units for education, health, agriculture, environment, vital registration, and development and planning. On the other hand, less than one quarter of local governments have created governmental units for FM radio, alternative 
energies, forest/biodiversity, language/culture, and transportation.

On the relationship between local governments and wards, only one local government reported that there was no clear allocation of authority between the local government and the wards. In 82 percent of local governments, ward chairs were clear about their roles. Surprisingly enough, this percentage goes down to 65 in metropolitan local governments. More than half ( 57 percent) of local governments reported no disputes between ward chairs and mayors; though Karnali has more disputes than other provinces, particularly around the devolution of authority and office location. 88 percent of local governments reported that their wards meet at least monthly. Sudur Pashchim had the fewest local governments with wards that held monthly meetings (58 percent).

\section{Sector Administrative Capacity}

Sectoral administrative capacity amongst local governments varies across sectors, ecological zones and provinces. To manage and conduct sector level policies and work, at the minimum, local governments need to incorporate sectors into their organizational structures. To that extent, the incorporation rate of sectors into organization structure of individual local governments are above fifty percent for most sectors. Some sectors like education, basic health, social welfare related sectors, agriculture and local roads have been incorporated by over 90 percent of local governments (

Table 13).

Sectors related to economic development, except for cooperative sectors (89 percent) have modest incorporation rates. Micro enterprise and economic data collection are incorporated by 56 percent and 55 percent of local governments respectively, but only 6 percent of local governments have unemployment records. Similarly, sectors related to the environment also have only modest incorporation rates amongst local governments. Bio-diversity and watershed sectors have been incorporated by 52 percent of local governments while wildlife and mines \& minerals sectors have only been incorporated by 37 percent and 27 percent respectively.

Table 13. Portion of Local Governments That Have Incorporated Sectors into Their Organizational Structures

\begin{tabular}{|c|c|c|c|}
\hline Disaster Risk Management & $77 \%$ & Fisheries & $35 \%$ \\
\hline Education & $98 \%$ & Agriculture Extension & $62 \%$ \\
\hline Basic Health Services & $97 \%$ & Horticulture & $71 \%$ \\
\hline Social Welfare & $95 \%$ & Irrigation & $66 \%$ \\
\hline Vital Registration & $95 \%$ & Forest & $52 \%$ \\
\hline Women & $95 \%$ & Bio-diversity & $52 \%$ \\
\hline Children & $95 \%$ & Watershed & $37 \%$ \\
\hline Youth & $81 \%$ & Wildlife & $27 \%$ \\
\hline Senior Citizens & $95 \%$ & Mines \& Minerals & $27 \%$ \\
\hline
\end{tabular}




\begin{tabular}{|c|c|c|c|}
\hline Sports & $84 \%$ & Soil Conservation & $60 \%$ \\
\hline Unemployment Records & $6 \%$ & Waste Management & $77 \%$ \\
\hline Cooperative & $89 \%$ & Community Parks & $76 \%$ \\
\hline Local Market Management & $70 \%$ & Environmental \\
Management & $83 \%$ \\
\hline Micro Enterprise & $56 \%$ & Drinking Water & $87 \%$ \\
\hline Economic Data Collection & $55 \%$ & Sanitation & $97 \%$ \\
\hline Local Economic Development Plan & $63 \%$ & Local Roads & $85 \%$ \\
\hline Agriculture & $95 \%$ & Rural Roads & $63 \%$ \\
\hline Agriculture Production & $72 \%$ & Agricultural Roads & \\
\hline
\end{tabular}

Source: Estimated by the study team based on a representative survey of local governments.

As noted above, there are regional disparities in capacities amongst local governments. While the FCNA dataset has rich information on all sectors about regional variances, this note will illustrate this with reference to two sectors.

Local governments across the country have an overall incorporation rate of 83 percent and 87 percent for drinking water and sanitation respectively. However, compared amongst provinces, the incorporation rate of drinking water varies from 90 percent (Province 1 and Province 6) to 75 percent (Province 4). Similarly, all Province 2 local governments have incorporated sanitation into their organizational structures but only 60 percent of local government have done so in Karnali (Province 6) (

Table 14).

Table 14. Drinking Water and Sanitation Functions Incorporated into Local Governments, by Province

\begin{tabular}{|c|c|c|}
\hline & Drinking Water & Sanitation \\
\hline Province 1 & $90 \%$ & $90 \%$ \\
\hline Province 2 & $77 \%$ & $100 \%$ \\
\hline Province 3 & $80 \%$ & $85 \%$ \\
\hline Province 4 & $75 \%$ & $83 \%$ \\
\hline Province 5 & $83 \%$ & $94 \%$ \\
\hline Province 6 & $90 \%$ & $60 \%$ \\
\hline Province 7 & $83 \%$ & $75 \%$ \\
\hline Total & $\mathbf{8 3 \%}$ & $\mathbf{8 7 \%}$ \\
\hline
\end{tabular}


Source: Estimated by the study team based on a representative survey of local governments.

There is variance in the development and incorporation of settlement/urban master plans and land use plans across ecological regions. Across the country, only 17 percent of local governments have settlement masterplans and 60 percent have land use plans. However, there is also difference across the ecological zones as illustrated by

Table 15. More local governments in the TEZ have settlement master plans than in the Himalayan Ecological Zone (HEZ) or Hilly Zone. Similarly, more TEZ local governments have land use plans than HEZ or Hilly Zone local governments.

Table 15. Portion of Local Governments with No Master Plan and No Land Use Plan, by Ecological Zone and Municipality Type

\begin{tabular}{|c|c|c|}
\hline & No Master Plan & No Land Use Plan \\
\hline HEZ & $88 \%$ & $53 \%$ \\
\hline Hilly Zone & $88 \%$ & $39 \%$ \\
\hline TEZ & $76 \%$ & $37 \%$ \\
\hline Metro & $76 \%$ & $29 \%$ \\
\hline Urban & $83 \%$ & $25 \%$ \\
\hline Rural & $85 \%$ & $43 \%$ \\
\hline All Local Governments & $83 \%$ & $40 \%$ \\
\hline
\end{tabular}

Source: Estimated by the study team based on a representative survey of local governments.

Sources of sector funding at local governments vary across sectors. The results from the local government survey illustrating the sources of funds utilized by local governments by sector are presented in

Table 16 below. Most local governments use revenue sharing funds for economic development (79 percent). Similarly, most local governments prioritize their own source revenue for economic development (78 percent) as well. Own source revenue is also used by many local governments in all other sectors apart from basic health service. No local government uses own source revenue for basic health services.

Nearly all local governments (99 percent) use conditional grants for basic health services. In addition to basic health service, most local governments use conditional grants for education (97 percent), economic development (90 percent) and agriculture (83 percent). Social development is the only sector where no local governments use conditional grants as a funding source.

Equalization grants are the most favored funding source for social development, with 79 percent of local governments using it. Other sectors where equalization grants are commonly 
used are agriculture (76 percent), environment (76 percent) and basic health services (65 percent). However, no local government uses equalization grants for drinking water and sanitation and road sectors.

Complementary grants are mostly used by local governments for economic development (90 percent), roads ( 86 percent) and drinking water and sanitation ( 71 percent). While there is at least one local government utilizing complementary grants in each of the other sectors, the use is much lower. For example, the next most common uses of complementary grants are for the environment and social development sectors, with only 17 percent and 16 percent of local governments utilizing it respectively.

In the case of special grants, no local government uses it for education, environment or drinking water and sanitation. The most common use of special grants by local governments is for economic development ( 25 percent) followed by roads ( 17 percent).

Table 16. Percentage of Local Governments Using the Different Funding Sources for Each Sector

\begin{tabular}{|l|l|l|l|l|l|l|}
\hline & Own Source & Revenue Sharing & $\begin{array}{l}\text { Complementary } \\
\text { Grant }\end{array}$ & Conditional Grants & Special Grants & Equalization Grants \\
\hline Education & $47 \%$ & $23 \%$ & $10 \%$ & $97 \%$ & $0 \%$ & $56 \%$ \\
\hline Basic Health Services & $0 \%$ & $16 \%$ & $10 \%$ & $99 \%$ & $4 \%$ & $65 \%$ \\
\hline Social Development & $61 \%$ & $42 \%$ & $16 \%$ & $0 \%$ & $13 \%$ & $79 \%$ \\
\hline Economic Development & $78 \%$ & $79 \%$ & $90 \%$ & $90 \%$ & $25 \%$ & $43 \%$ \\
\hline Agriculture & $61 \%$ & $25 \%$ & $9 \%$ & $83 \%$ & $13 \%$ & $76 \%$ \\
\hline Environment & $56 \%$ & $39 \%$ & $17 \%$ & $50 \%$ & $0 \%$ & $76 \%$ \\
\hline Drinking Water \& Sanitation & $62 \%$ & $45 \%$ & $71 \%$ & $58 \%$ & $17 \%$ & $0 \%$ \\
\hline Roads & $59 \%$ & $63 \%$ & $86 \%$ & $58 \%$ & $0 \%$ \\
\hline
\end{tabular}

Source: Estimated by the study team based on a representative survey of local governments.

Performance monitoring capacity is a major issue across all sectors for many local governments. Many local governments do not have any personnel, resources, knowledge or physical infrastructure to monitor sector-level performance and outcomes. Sector-wise, settlement development, environment, disaster risk management, drinking water and sanitation, and agriculture had the largest portion of local governments without either any personnel, resources, knowledge or physical infrastructure to monitor performance (

Table 17).

Lack of resources was the most commonly identified capacity-related challenge that constrained performance monitoring in local governments. As much as 30 percent of local governments do not have any resources to monitor performance of settlement development followed by environment ( 24 percent) and drinking water and sanitation ( 23 percent). Roads is the only sector where over 10 percent of local governments (13 percent) have adequate 
resources to monitor performance. In the other sectors, less than 10 percent of local governments have adequate resources.

In the case of personnel and skills for monitoring, it was only basic health services (28 percent) and roads ( 21 percent) which saw more than 20 percent of local governments having adequate capacity. Some 34 percent of local governments have no capacity regarding personnel and skills for monitoring environment while 32 percent of local governments do not have it for settlement development. Only settlement development (25 percent), environment (15 percent) and drinking water and sanitation (10 percent) had more than 10 percent of local governments having no knowledge for monitoring. In contrast to the other capacities, a higher proportion of local governments had knowledge to monitor performance, albeit, it is still very low. The sector with the greatest number of local governments having adequate knowledge was the basic health services sector (38 percent).

Table 17. Portion of Local Governments with "Adequate Capacity" and "No Capacity" for Monitoring Outcomes and Performance in Each Sector

\begin{tabular}{|l|l|l|l|l|l|l|l|l|}
\hline & \multicolumn{2}{|l|}{ Personnel/Skills } & \multicolumn{2}{l}{ Resources } & \multicolumn{2}{l}{ Knowledge } & \multicolumn{2}{l|}{ Physical Infrastructure } \\
\cline { 2 - 9 } & Adequate & None & Adequate & None & Adequate & None & Adequate & None \\
\hline $\begin{array}{l}\text { Settlement Development } \\
\text { Land Administration }\end{array}$ & $6 \%$ & $32 \%$ & $5 \%$ & $30 \%$ & $17 \%$ & $25 \%$ & $10 \%$ & $34 \%$ \\
\hline Disaster Risk Management & $3 \%$ & $22 \%$ & $5 \%$ & $18 \%$ & $18 \%$ & $5 \%$ & $1 \%$ & $27 \%$ \\
\hline Education & $17 \%$ & $12 \%$ & $5 \%$ & $11 \%$ & $27 \%$ & $4 \%$ & $8 \%$ & $9 \%$ \\
\hline Basic Health Services & $28 \%$ & $3 \%$ & $6 \%$ & $8 \%$ & $38 \%$ & $3 \%$ & $8 \%$ & $10 \%$ \\
\hline Economic Development & $14 \%$ & $8 \%$ & $7 \%$ & $10 \%$ & $23 \%$ & $4 \%$ & $10 \%$ & $9 \%$ \\
\hline Agriculture & $11 \%$ & $14 \%$ & $7 \%$ & $17 \%$ & $29 \%$ & $7 \%$ & $5 \%$ & $19 \%$ \\
\hline Environment & $6 \%$ & $34 \%$ & $5 \%$ & $24 \%$ & $16 \%$ & $15 \%$ & $6 \%$ & $31 \%$ \\
\hline Drinking Water \& Sanitation & $11 \%$ & $17 \%$ & $7 \%$ & $23 \%$ & $19 \%$ & $10 \%$ & $6 \%$ & $16 \%$ \\
\hline Roads & $21 \%$ & $4 \%$ & $13 \%$ & $8 \%$ & $37 \%$ & $3 \%$ & $11 \%$ & $9 \%$ \\
\hline
\end{tabular}

Source: Estimated by the study team based on a representative survey of local governments.

\section{Gender Equality and Social Inclusion}

At least 80 percent of local governments have Gender Equality and Social Inclusion (GESI) policies, including those for children, senior citizens, and the differently-abled, as well as for ensuring women's participation in local government activities. However, 60 percent of local governments have never conducted a GESI audit. Nearly all local governments have included GESI in their budgets and through inclusiveness that encourages the participation of women and senior citizens, as well as ethnic and disadvantaged groups. To combat gender-based violence, nearly all local governments have awareness campaigns, four fifths provide counselling services, and two thirds provide monitoring. More than one half provide legal 
services and special programs, with 30 percent providing compensation to support victims. While only 2 percent of local governments reported having none of these programs, 10 percent local governments in Province 6 have no programs. Provinces 2 and 7 have enacted legislation against gender-based violence; Provinces 2 and 6 have legal support for victims; and Provinces 2, 4, and 7 have victim compensation provision.

\section{Accountability \& Transparency}

Local governments use a variety of methods to make their executive decisions public. The most important tools include: a website ( 70 percent of local governments), notice boards (59 percent), social media (59 percent), newspapers (46 percent), public announcements (44 percent), and radio/TV (41 percent). There were some ecological zone differences, such as HEZ local governments being less likely to use websites (59 percent) and more likely to use notice boards ( 82 percent). Websites are also the common method used to inform citizens about services provided by the local government, with 81 percent of local governments using them. Using the Citizen Charters was the next most common ( 73 percent), followed by social media (66 percent), and advertisements (59 percent).

The frequency of making public income and expenditure statements varied greatly, with 26 percent doing so semi-annually, 23 percent monthly, 18 percent quarterly and 15 percent annually. 17 percent of local governments never make their income and expenditure statements public. While nearly all local governments use the federal act to implement Right to Information, and only 8 percent receive requests for information "frequently", with metropolitan local governments more likely to get frequent requests. Nearly all local governments (92 percent) have a designated information officer that is made public.

Budgets, plans, assembly decisions, and executive decisions are made public by more than 90 percent of local governments, with 82 percent providing details about activities and performance of thematic sections. Nearly all local governments have websites that provide the following details: contact of officials (94 percent); policies, plans, and programs (94 percent); updates of local government activities (90 percent); laws and regulations (90 percent); and budget information (92 percent).

Local governments engage external organizations in budget preparation at generally high but varying rates, with local business chambers and civil society/NGOs recording the highest (at 83 percent of local governments). Fewer local governments engage community associations or other public institutions ( 76 percent and 64 percent, respectively). Province 2 is less likely to engage outside organizations than other provinces, and Hilly Zone local governments are more likely to do so.

Some 83 percent of local governments have a grievance redress mechanism. These local governments mostly use designated officials and complaint boxes ( 86 percent and 83 percent respectively), followed by public hearings (75 percent), social media (64 percent), social audits (61 percent), and complaint registers (51 percent). In the 96 (out of 115 sampled) local governments that have a grievance redress system, the average number of complaints registered was 16 , with a wide variance ( 0 to 356 ); the average number of complaints addressed was nine. Three quarters of local governments conducted a social audit for the recent fiscal year. The most common reason for not conducting a social audit was "limited 
personnel", cited by 57 percent of those not conducting the audit.

\section{Recommendations}

With the outbreak of the coronavirus pandemic the federal system has been put to a test in Nepal. Subnational governments have joined the federal government's efforts in fighting against the ongoing pandemic. The joint efforts of all levels of government managed to contain the spread of the disease. Although there is already a high prevalence in its neighboring countries, the outbreak of the coronavirus pandemic has not been too alarming in Nepal. The provincial and local governments are working closely with the federal government to fight the coronavirus pandemic. A provincial disaster management committee has been activated in all seven provinces. Local governments are collecting data in terms number of the people in quarantine/isolation, returned from abroad, needing relief, and are executing plans to provide them with food ration. They have also set up isolation and quarantine facilities in different places. The citizens are being educated of preventive measures to fight the virus. The volunteers and health workers deployed by the local governments are screening people for fever and other symptoms.

However, to maximize the chances of reaching the objectives of federalism, an appropriate ordering of the reforms process is needed for several reasons. First, sequencing the reform process will ensure that government maintains focus on pre-defined goals, undertakes complementary reforms (where necessary), while anticipating potential opportunities and risks to the successful implementation of federalism. For instance, various areas which require capacity building might be recognized early, and proactive action could be taken in anticipation of next steps. Otherwise, the process could be stalled at various stages, and implemented programs would likely be half-finished.

Second, developing a sequenced reform plan could help identify potential political economy factors which could affect the implementation of reforms.

Third, a sequenced plan would also help reduce the adjustment costs associated with the introduction of federalism. High costs of reforms could arise from lengthy debates over policy choices, duplication of policy actions and poor coordination, attributable to the absence of a documented and agreed sequenced plan. Part of the costs could also stem from policy missteps, coupled with lengthy debates and digressions, which could arise because of the absence of a documented sequenced plan.

Some of the unintended costs of ignoring a well sequenced strategy may yield mild inefficiency costs regarding suboptimal financing of investments. However, others could have broader and more devastating ramifications. For instance, granting significant borrowing powers to subnational governments without context-relevant borrowing and debt rules could place the country's economy on an unsustainable debt trajectory: that is, cause macroeconomic instability because of a strong temptation to indulge in fiscal indiscipline. A closely related and ubiquitous sequencing misstep involves the assignment of revenue responsibilities before clearly defining the expenditure functions. This could culminate in inefficient allocation of funds and create fiscal deficit difficulties (because investment returns may be inadequate to recoup investment costs) resulting in macroeconomic instability.

A good approach would be to put an implementation plan in place and allow it to be adjusted 
as the process moves forward. If the implementation plan is annotated with an action plan, it could form a basis for monitoring the progress of the overall federalism process. The responsibility for developing the implementation plan needs not solely be with one level of government or a single ministry. A "Roadmap Committee" could be entrusted to design the implementation plan. Ideally, the committee should have representation from major stakeholders, as well as entail technical staff. For example, it could be a body chaired by the Prime Minister, with members from MOFAGA, the Inter-Provincial Council, the local government associations, and a distinguished intergovernmental fiscal expert from outside government. A natural home for the committee might be the Inter-Provincial Council, or it might be established under the Intergovernmental Coordination Bill (Art. 235 of the Constitution), if this idea could get buy-in from the other important stakeholders. Once the roadmap is in place and accepted by the Committee, its management and regular upgrading could be handed to another body for tracking and updating.

\section{References}

Bahl, R., \& Martinez-Vazquez, J. (2013) Sequencing Fiscal Decentralization. Annals of Economics and Finance, 14-2 (B), 623-670.

Berger, L. (2018). Grant systems for sub-national governments - some basics and issues for Nepal. Preliminary estimates presented to the NNRFC during a workshop conducted by Ron Hackett, PFMSP PFM Advisor, Dec 13, Kathmandu.

Dickovick, J. T. (2014). Foreign Aid and Decentralization: Limitations On Impact in Autonomy and Responsiveness. Public Admin. Dev., 34, 194-206. https://doi.org/10.1002/ pad.1691

Edwards, B., \& Yilmaz, S. (2016). Decentralization as a Post-Conflict Stabilization Tool: The Case of Sierra Leone. Public Admin. Dev., 36, 347-358. https://doi.org/10.1002/pad.1784

Georgia State University. (2019). Federalism Capacity Needs Assessment (FCNA). Available at https://www.mofaga.gov.np/uploads/notices/Notices-20200506153437737.pdf

Kim, Doo-Rae \& Jong-Han, Y. (2018) Decentralization, Government Capacity, and Environmental Policy Performance: A Cross-National Analysis. International Journal of Public Administration, 41(13), 1061-71. https://doi.org/10.1080/01900692.2017.1318917

McCourt, W. (2018). New directions for public service reform in developing countries. Public Admin Dev, 38, 120-129. https://doi.org/10.1002/pad.1833

Rao, S. S., \& Kothai, K. (2019). Decentralization in India's health sector: insights from a capacity building intervention in Karnataka. Health policy and planning, 34(8), 595-604. https://doi.org/10.1093/heapol/czz081

Rocha, F., Veronica, F. O., \& Marislei, N. (2016). Health spending autonomy and infant mortality rates: A matter of local administrative capacity? The Journal of Developing Areas, 50(2), 293-309. https://doi.org/10.1353/jda.2016.0092

World Bank. (2018). Building Sustainability in an Urbanized World. Urban Development Series Knowledge Papers.

\section{Notes}

${ }^{1}$ https://www.mofaga.gov.np/uploads/notices/Notices-20200506153437737.pdf 
${ }^{2}$ The study used a broad definition of capacity, including organizational (physical and human) and institutional (laws and regulations) elements in assessing capacity constraints at the subnational level. The FCNA surveyed a sample of 115 of the 753 local governments and all seven provincial governments. It also conducted desk review and informant interviews of public officers.

${ }^{3}$ The first phase of the local elections in 20 years was held on May 14, 2017, in 34 districts of Nepal. Following this, local elections were carried out in most of the remaining districts on June 28, 2017, while the elections in province no. 2 were postponed to September 18, 2017. With the parliament dissolved on October 13, 2017, the general and provincial elections were held on November 26, 2017 (32 districts) and December 7, 2017 (45 districts).

${ }^{4}$ The Constitution puts forward a list of federal, provincial and concurrent powers for 33, 21 and 25 functions, respectively.

${ }^{5}$ Residual powers are functions that are not enumerated in the Constitution.

6 The distribution of taxation powers amongst three triers of government is listed in Schedules 5 to 9 . Schedule 5 specifies revenue sources for the federal government, schedule 6 for the provinces and schedule 8 for the local governments. Schedules 7 and 9 relate to concurrent matters in revenue raising between federal and provincial governments and amongst federal, provincial and local governments respectively. The major sources of revenue to be shared with federal and subnational governments include custom duty, value added tax, excise duty, corporate income tax and personal income tax.

${ }^{7}$ Provincial and local governments are responsible for the collection of entertainment tax, advertisement tax, and registration fee for land and property. Local governments are responsible for the collection of property tax, land revenue, vehicle tax, business tax and house rent tax.

${ }^{8}$ Such as royalties from natural resources and tourism fees.

${ }^{9}$ This tax sharing entitlement was allocated for the first time in FY 2018/2019. As used in Nepal, it is a direct claim against national tax collections rather than a transfer from the consolidated fund. It is not explicitly provided for in the Constitution. Note also that because of this feature, the national budget does not classify the tax sharing grant as an intergovernmental transfer to subnational governments.

${ }^{10}$ Since the NNRFC Committee members are not appointed yet, so far it was only the NNRFC Secretariat who decided on the formulae. But after the appointment of the Committee member, the formulas need to be approved by the Committee.

${ }^{11}$ The first fiscal year for the provincial governments.

${ }^{12}$ Subnational governments can pass tax laws as long as their laws do not conflict with tax jurisdiction provisions, exclusive and concurrent list as defined in the Constitution and the Intergovernmental Fiscal Arrangement Act.

${ }^{13}$ The Parliament approved the Civil Servants Adjustment Act on 6 October 2017, paving the way for placement of civil servants across the three layers of government-local, provincial and federal. The Act sets up three key criteria - seniority of civil servants, their permanent addresses and their preferences in terms of which of the three levels of government they wish to serve in-for their deployment at the subnational levels.

14 This civil service number is as of February 5, 2019 and includes health personnel but excludes teachers.

${ }^{15}$ The O\&M survey method used for the federal government relied on a request for needed employment from each Ministry, accompanied by "expert judgement" by MOFAGA officials. At the subnational level, the approach was similar but relied more heavily on expert 
judgement by MOFAGA officials.

${ }^{16}$ There is no objective way of judging whether a total reduction of 46 percent of the federal civil servants (or one third of the total government workforce, excluding teachers) is ideal, too much or too little. A possible yardstick or international comparison is not very helpful in this regard because the assignment of expenditure responsibilities and the classification of employees differ across countries.

${ }^{17}$ It is equivalent to a 6-percent reduction in the number of civil service positions that the federal government will retain in their ministries.

${ }^{18}$ The provincial and local governments also have the authority to carry out their own O\&M surveys to determine their staffing needs. However, without provincial public service commissions in place, they would have to rely on the federal civil service commission to carry out recruitment.

19 The MOFAGA O\&M for Province Governments is as of July 17, 2018. At the subnational level, the approach used was based on expert judgement by MOFAGA officials.

${ }^{20}$ Teachers are excluded.

21 MOFAGA requested civil servants to submit their preferred level of government service. Of the approximately 77,000 civil servants who responded, 46 percent chose federal, 18 percent province, and 36 percent local.

22 The federal and subnational governments also hire workers on a contractual basis to perform operational tasks. Such individuals are hired directly by ministries at the federal level, and they are not a part of the civil service. MOFAGA estimates that there are about 10,000 contractual workers on the federal government payroll, and about 10,000 at the provincial and local level. (The FCNA survey estimates are that there are about 20,000 positions filled with contractual employees at the local level). However, these employees are unlikely to meet the qualifications to fill civil service management positions since many (most) are drivers, messengers, cleaners, computer operator etc.

${ }^{23}$ Legacy staff at the local governments are permanent employees hired directly by previous Village Development Committees and nagar palikas but have been retained by and adjusted to successor local governments.

${ }^{24}$ The reserve pool of civil service employees is those who have not been assigned to any position during the adjustment process. They will also be assigned positions to fill the remaining gaps taking into account their skills, expertise, and other non-professional attributes.

${ }^{25}$ Meetings of World Bank team and MOFAGA officials on December 7, 2018, and during the January-March period of 2019.

${ }^{26}$ In Province 6 all local governments have solar power.

${ }^{27}$ Nationwide counts were derived from the sample using proportions of different strata in the total universe of all local governments.

\section{Copyrights}

Copyright for this article is retained by the author(s), with first publication rights granted to the journal.

This is an open-access article distributed under the terms and conditions of the Creative Commons Attribution license (http://creativecommons.org/licenses/by/4.0/). 